\title{
A csípőtáji törést elszenvedett betegekre vonatkozó adatvaliditási vizsgálat egy magyarországi kórházban
}

\author{
Surján Cecília - Belicza Éva dr. \\ Semmelweis Egyetem, Egészségügyi Közszolgálati Kar, Egészségügyi Menedzserképző Központ, Budapest
}

Bevezetés: A csípőtáji törések jelentősen terhelik az egészségügyi ellátórendszereket. Magyarországon $13000-15000$ beteg szenved évente csípőtáji törést, jelentős részük mútéten is átesik. A betegek túlélését vizsgálták a EuroHOPE és BRIDGE kutatások, amelyek a Nemzeti Egészségbiztosítási Alapkezelőnek a finanszírozási célból gyűjtött, esetszintû adataira támaszkodtak. Az ilyen jellegư adatok megbízhatóságát több kutatás vizsgálta eltérő eredményekkel, ezért a további vizsgálatok előtt szükségesnek tartottuk a csípőtáji törésekre vonatkozóan is ellenőrizni őket.

Célkitüzés: Egy magyarországi kórház reprezentatívan kiválasztott eseteinek vizsgálatán keresztül annak megállapítása, hogy a finanszírozási adatbázis adatai megfelelnek-e a betegdokumentációban rögzített adatoknak.

Módszer: Egy magyarországi kórházba 2015-ben csípőtáji töréssel felvett betegek kórlapjainak anonim, reprezentatív mintáját összevetettük a EuroHOPE és BRIDGE kutatások adatbázisával tíz különböző adatelemre vonatkozóan. Az adatbázisokat rekordszinten párosítottuk, az egyezést adatelemre és rekordra vonatkozóan néztük.

Eredmények: A reprezentatív minta 259 esetet tartalmazott. Az adatbázisok összevetése során nem találtunk eltérést a beteg neme, életkora, ápolást indokló fődiagnózisa és az osztályról történő távozás dátuma esetén. Egy eltérést találtunk az osztályos felvétel dátumában, a mưtét dátumában öt darabot. A beteg további sorsa esetén tíz eltérést találtunk. A mútéttípusok esetén is alacsony mértékű (2-4 eset) eltérést tapasztaltunk. Jelentős mértékű eltérést a társbetegségek és a szövődmények esetén találtunk.

Következtetés: Eredményeink alapján további vizsgálatokhoz felhasználhatók az alfanumerikus kódokat, számokat vagy dátumokat tartalmazó mezők (például fődiagnózis, felvételi és távozási dátumok), a társbetegségekre és a szövődményekre vonatkozó adatok azonban nem alkalmazhatók mélyebb elemzések során.

Orv Hetil. 2021; 162(18): 712-719.

Kulcsszavak: csípőtáji törés, validitási vizsgálat, adatminőség

\section{Examination of data validity of hip fracture patients in a Hungarian hospital}

Introduction: Hip fractures pose a heavy burden on healthcare systems. In Hungary, 13 000-15 000 patients experience hip fractures, most of them undergo surgery. Their survival was examined by the EuroHOPE and BRIDGE studies, using patient level data from the National Health Insurance Fund. Data from healthcare financing reports have been examined worldwide, with contradicting results, so we considered it necessary to observe data validity for hip fractures before further analysis.

Objective: The aim of our study was to observe a representative sample of patient records in a Hungarian hospital in order to validate the finance reports.

Method: We matched a representative sample of hip fracture patient records in a Hungarian hospital with hip fractures in 2015 with the database of the EuroHOPE and BRIDGE studies. The databases were matched on record level, the analysis included ten data fields and was conducted for data fields and records.

Results: The sample included 259 cases. No differences were observed in the patients' gender, age and main diagnosis, or dates of discharge. One difference was observed in the dates of admission, and 5 in the dates of surgery. Minor differences were found in the types of surgery (2-4 cases), but the differences between the databases in comorbidities and complications were large.

Conclusion: Based on our results, we can conclude that data fields containing alphanumeric codes, numbers or dates (e.g., main diagnosis, admission, discharge and surgery dates) can be used for further analysis, but comorbidity and complication data are not recommended for research purposes.

Keywords: hip fractures, validation study, data quality

Surján C, Belicza É. [Examination of data validity of hip fracture patients in a Hungarian hospital]. Orv Hetil. 2021; 162(18): 712-719.

(Beérkezett: 2020. augusztus 4.; elfogadva: 2020. október 13.) 


\section{Rövidítések}

ÁEEK = Állami Egészségügyi Ellátó Központ; BNO = Betegségek Nemzetközi Osztályozása, 10. revízió; DHS = (dynamic hip screw) dinamikus csípőcsavar; EuroHOPE-BRIDGE = EuroHOPE és BRIDGE Health projektek; OENO = Orvosi Eljárások Nemzetközi Osztályozása; NEAK = Nemzeti Egészségbiztosítási Alapkezelő; OEP = Országos Egészségbiztosítási Pénztár; taj = társadalombiztosítási azonosító jel

A csípőtáji törések és az ebből fakadó ellátási feladatok jelentős terhet rónak az egészségügyi ellátórendszerre. Magyarországon évente 13 000-15 000 beteg szenved csípőtáji törést, akiknek többsége, kb. 87-89\%-uk mútéten is átesik a törés kezelésének érdekében [1]. Korábbi nemzetközi kutatások, a EuroHOPE és folytatásaként a még nem publikált BRIDGE-Health (a továbbiakban EuroHOPE-BRIDGE) projektek több európai országban vizsgálták a csípőtáji törést elszenvedő betegek sorsát 2006 és 2015 között. Az eredmények alapján Magyarországon kiemelkedően magas a betegek korai, a törés diagnózisával történt kórházi felvételt követő l-3 hónapon belüli halálozása [1]. A kutatáshoz felhasznált adatokat az Országos Egészségbiztosítási Pénztár (OEP, ma Nemzeti Egészségbiztosítási Alapkezelő, NEAK) finanszírozási céllal gyújtött betegforgalmi adatbázisából a jelenlegi Állami Egészségügyi Ellátó Központnak (ÁEEK) átadott, anonimizált, tisztított adatokból válogattuk le. A betegadatok jelentésének célja a kórház teljesítményének a finanszírozó felé történő elszámolása, ez pedig hatással lehet a jelentett adattartalom minőségére [2].

Nemzetközi szinten több kutatás vizsgálja a finanszírozási célú jelentések, adatállományok megbízhatóságát [3-7]. Ezek konklúziói szerint előfordulhatnak nagymértékű eltérések is az orvos által megállapított diagnózisok és egyéb lejegyzett adatok, illetve a továbbított jelentések tartalma között.

A betegek halálozását jelentős mértékben befolyásolják egészségi állapotuknak a törés bekövetkeztekor már fönnálló egyéb jellemzőii [8-10]. Ezért a finanszírozási adatbázisra támaszkodó, az ellátás eredményére vonatkozó mélyebb elemzések előtt végzett adatminőség-vizsgálatunk során nemcsak az ellátáshoz kapcsolódó, hanem a jelentett betegjellemző́k és társbetegségek megfelelőségét is át kell tekintenünk. Meg kell állapítanunk, hogy a finanszírozási adatbázisban szereplő esetek valóban csípőtáji törést elszenvedett betegek-e, illetve a kórlapon rögzített mútéti jellemzők helyesen jelennek-e meg. Kiemelt figyelmet érdemel ezek között a mủtéti időpont rögzítésének helyessége, hiszen a szakirodalom szerint a kórházi felvétel és a múttét között eltelt idő fontos, túlélést befolyásoló tényező [11-13].

Kutatásunk célja volt, hogy egy magyarországi kórház reprezentatívan kiválasztott eseteinek vizsgálatán keresztül megállapítsuk, hogy a finanszírozási adatbázis adatai megfelelnek-e a betegdokumentációban rögzített adatoknak, és az eredmények alapján vélelmezni lehessen az adatbázis alkalmasságát mélyebb adatelemzésekhez.

A vizsgálatot a Kórházi Kutatásetikai Bizottság engedélyével és az adatbiztonsági feltételek betartásával, a betegek személyiségi jogainak védelmét garantálva végeztük el. Az elemzési adatbázisban a beteg neve, társadalombiztosítási azonosító jele (taj), születési dátuma és lakcíme nem szerepelt, az adatok feldolgozása az intézményen belül, elkülönített helyiségben történt, külső adathordozóra, hálózatra személyazonosításra alkalmas információk nem kerültek.

\section{Módszer}

A EuroHOPE-BRIDGE kutatás 2005 és 2015 között vizsgálta a csípótáji törést elszenvedett betegek ellátási jellemzőit. A vizsgálatba olyan betegek kerültek be, akik esetében az ápolást indokló fódiagnózis a Betegségek Nemzetközi Osztályozásának 10. revíziója szerint (BNO-10) S72.0 (a combnyak törése), S72.1 (pertrochanter törés) vagy $\$ 72.2$ (subtrochanter törés) volt, betöltötték az 50. életévüket, a vizsgált országok állampolgárai voltak, és a vizsgált, felvételt megelőző 365 napban nem kerültek a vizsgált kódokkal kórházi felvételre.

1. táblázat | Bevonási és kizárási kritériumok az intézményi adatleválogatás és a EuroHOPE-BRIDGE projekt során

\begin{tabular}{|c|c|c|c|}
\hline & & Kórházi adatbázis & EuroHOPE-BRIDGE projekt \\
\hline \multirow[t]{5}{*}{$\begin{array}{l}\text { Bevonási } \\
\text { kritériumok }\end{array}$} & $\begin{array}{l}\text { Ápolást indokló fódiagnózis a } \\
\text { BNO-10 szerint }\end{array}$ & \multicolumn{2}{|l|}{$\mathrm{S} 72.0, \mathrm{~S} 72.1, \mathrm{~S} 72.2$} \\
\hline & A leválogatás alapegysége & Osztályos eset & Akut osztályos ellátással kezdődő kórházi eset \\
\hline & Az osztályos felvétel időpontja & \multicolumn{2}{|l|}{ 2015.01.01.-2015.12.31. } \\
\hline & Életkor & \multicolumn{2}{|l|}{$\geq 50$ év } \\
\hline & Állampolgárság & \multicolumn{2}{|l|}{ Magyar } \\
\hline \multirow{3}{*}{$\begin{array}{l}\text { Kizárási } \\
\text { kritériumok }\end{array}$} & \multirow[t]{2}{*}{ A felvétel jellemzői } & Rehabilitációs osztályos felvétel & \multirow{2}{*}{$\begin{array}{l}\text { Az esetet megelőző } 365 \text { napban olyan kórházi } \\
\text { felvétel, amelynél az ápolást indokló fődiagnózis } \\
\text { S72.0, S72.1 vagy S72.2 }\end{array}$} \\
\hline & & Más osztályról átvett beteg & \\
\hline & A beteg jellemzói & \multicolumn{2}{|l|}{ Patológiás törés } \\
\hline
\end{tabular}

BNO = Betegségek Nemzetközi Osztályozása 
2. táblázat |Az adatvaliditási vizsgálathoz a kórházi adatbázisból felhasznált adatelemek, adatforrásaik és az egyezés kritériumai a EuroHOPE-BRIDGE adatokkal

\begin{tabular}{lll}
\hline Adatelem & Az adatelem forrása & Az egyezés kritériuma a EuroHOPE-BRIDGE adatokkal \\
\hline Törzsszám & Kórlap fejléce & Kapcsoló mezó \\
\hline A beteg neme & Kórlap fejléce & Pontos egyezés \\
\hline A beteg életkora & Kórházi inf. adatbázis & Életévben elfogadott \pm 1 év \\
\hline Fódiagnózis & Kórlap kódolt mezóje & BNO-10 ötkarakteres egyezése \\
\hline Felvételi dátum & Kórlap fejléce & Osztályos felvételi dátum (év, hó, nap) pontos egyezés \\
\hline Távozási dátum & Kórlap fejléce & Osztályos elbocsátási dátum (év, hó, nap) pontos egyezés \\
\hline További sors & Epikrízis & Az epikrízisben szerepló információval való egyezés, a belsó áthelyezések nélkül \\
\hline A beteg társbetegségei & $\begin{array}{l}\text { Anamnézis, epikrízis, kódolt } \\
\text { diagnózis mezói }\end{array}$ & Ld. táblázat \\
\hline A mútét dátuma & Kórlap kódolt mezője & $\begin{array}{l}\text { Mútéti dátum (év, hó, nap) pontos egyezés } \\
\text { Külön jelölve: eltérés a kódolás és a dekurzus között }\end{array}$ \\
\hline A múttét típusa & Kórlap kódolt mezője & Ld. 4. táblázat \\
\hline
\end{tabular}

BNO = Betegségek Nemzetközi Osztályozása

A daganatos betegségek miatti patológiás töréseket kizárták a vizsgálatból [14].

$\mathrm{Az}$ adatvaliditás ellenőrzése érdekében egy nagy esetszámot ellátó magyarországi kórház reprezentatív mintáját vetettük össze a EuroHOPE-BRIDGE adatbázisban fellelhető adatokkal. Az összehasonlítást egy évre, 2015re korlátoztuk. A kórházi adatbázisból a rendszergazda segítségével azokat az osztályos eseteket válogattuk le, amelyeknél csípőtáji törés szerepelt ápolást indokló födiagnózisként, majd ezeket a törzsszám alapján párosítottuk a EuroHOPE-BRIDGE állomány rekordjaival. A bevonási és kizárási kritériumoknak (1. táblázat) megfelelő esetek közül a felvételi dátum szerint sorba rendezve minden 4. esetet választottuk ki részletes kórlapelemzésre. Az adatleválogatás a kórházi információs rendszeren keresztül elérhető kórlapok elektronikus, nem szerkeszthető verzióiból egyenként történt. A kórlap kódolt (strukturált) formában tartalmazta a beteg nemét, életkorát, a kórházi osztályra történő felvétel és elbocsátás dátumát, az ellátást indokló fódiagnózist és opcionálisan további diagnózisokat, valamint a beavatkozások dátumát és típusát. Szöveges, nem strukturált formában jelent meg az anamnézis, az ellátás folyamatát leíró dekurzus és a zárójelentésbe is átkerülő epikrízis.

A kórházi adatbázisból az 1. táblázatban szereplő feltételek alapján kiválasztott osztályos események kórlapjait elemeztük.

Az egyenlőség vizsgálata kézi módszerrel történt, tíz különböző adatelemre vonatkozóan (2. táblázat). Elsőként a kórházi adatbázison belül vizsgáltuk a szövegesen és kódoltan is leírt információk egyezőségét. Vizsgáltuk, hogy megegyezik-e az epikrízisben szövegesen és a BNO-kóddal leírt fódiagnózis, tehát valóban csípőtáji törést elszenvedett betegről van-e szó. A diagnózis helyességének, a mútét dátumának és típusának vizsgálatához összevetettük a kórlap szöveges mezőit (például a dekurzust, epikrízist) a kódolt mezőkkel (BNO, a mútét dátuma, típusa). A EuroHOPE-BRIDGE adatbázissal
3. táblázat |A EuroHOPE BRIDGE projektben vizsgált társbetegségek

\begin{tabular}{ll}
\hline A kutatásban vizsgált társbetegségek & $\begin{array}{l}\text { A BNO-10 szerinti kódok } \\
\text { a EuroHOPE-BRIDGE } \\
\text { állományban }\end{array}$ \\
\hline Magas vérnyomás & $\mathrm{I} 10^{*}-\mathrm{I} 15^{*}$ \\
Coronariabetegség & $\mathrm{I} 20^{*}-\mathrm{I} 25^{*}$ \\
Pitvarfibrilláció & $\mathrm{I} 48^{*}$ \\
Szívelégtelenség & $\mathrm{I} 50^{*}$ \\
Diabetes & $\mathrm{E} 10^{*}-\mathrm{E} 14^{*}$ \\
Atherosclerosis & $\mathrm{I} 70^{*}$ \\
Daganatos megbetegedés & $\mathrm{C} 00^{*}-\mathrm{C} 99^{*}, \mathrm{D} 00^{*}-\mathrm{D} 09^{*}$ \\
COPD és asztma & $\mathrm{J} 44^{*}-\mathrm{J} 46^{*}$ \\
Dementia & $\mathrm{F} 00^{*}-\mathrm{F} 03^{*}, \mathrm{G} 30 *$ \\
Depresszió & $\mathrm{F} 32^{*}-\mathrm{F} 34^{*}$ \\
Parkinson-kór & $\mathrm{G} 20^{*}$ \\
Mentális rendellenességek & $\mathrm{F} 20^{*}-\mathrm{F} 31^{*}$ \\
Veseelégtelenség & $\mathrm{N} 18^{*}$ \\
Alkoholbetegség & $\mathrm{F} 10^{*}-\mathrm{F} 19^{*}$ \\
Stroke & $\mathrm{I} 60^{*}-\mathrm{I} 69^{*}, \mathrm{G} 45^{*}$ \\
\hline A &
\end{tabular}

A kutatásban vizsgált szövődmények

Tüdőembólia I26*

Akut myocardialis infarctus I21*, I22*

Phlebitis és thrombophlebitis I80*, I81*, I82*

Pneumonia J12* $\mathrm{J13}^{*}, \mathrm{J14} 4^{*}, \mathrm{J15}$ *,

$\mathrm{J16*}, \mathrm{J17}^{*}, \mathrm{J18}$ *, J69*

Ortopédiai protézisekhez, implantá- $\quad$ T84.7

tumokhoz kötődő fertőzés

Húgyúti fertőzés N39.0

A *jelölés a táblázatban megadott 3 karakteres BNO-kódok összes 5 karakteres alábontását magában foglalja.

BNO = Betegségek Nemzetközi Osztályozása; COPD = krónikus obstruktív tüdőbetegség 
történő összevetéshez ezen adatelemek esetében a kódolt mezők adattartalmát használtuk fel. A társbetegségek, szövődmények és a beteg további sorsa tekintetében a kórlap szöveges adatmezőit vettük figyelembe. A szám, szöveg vagy alfanumerikus kód típusú adatmezők esetén az egyezés elbírálása bináris jelöléssel (igen/nem) történt. Egyenlőnek azok az esetek minősültek, amelyekben nem volt eltérés. Kivétel volt a beteg életkora, amelynél a kórházi adatbázis és a EuroHOPE-BRIDGE adatbázis eltérő számítási módszert alkalmazott, ezért egyévnyi eltérés előfordulhatott, ezeket egyezőnek tekintettük.

A betegek ellátás utáni további sorsának vizsgálatához az epikrízist vettük figyelembe, jelölve azokat az eseteket, amelyeknél a kórlapon eltérés volt tapasztalható a szöveg és a kódolt információ között (például ha a szöveges információ megnevezi a szociális otthont, ahova a beteg távozik, ám kódolva „otthonába bocsátva” szerepel a kórházi informatikai rendszerben). Mivel a EuroHOPE-BRIDGE kutatásban a további sors mezójében a kórházi és nem az osztályos elbocsátás szerepel, az egyezésvizsgálatból erre az adatelemre vonatkozóan kihagytuk a belső áthelyezéssel záruló eseteket.

A társbetegségek és a szövődmények adatvaliditási vizsgálata esetén a EuroHOPE-BRIDGE által figyelt diagnózisoknak a kórlapon szöveges formában való fellelhetôségét vizsgáltuk (3. táblázat). Amennyiben a kórlap tartalmazott társbetegségre vagy szövődményre utaló kódolt diagnózist, azt is bevontuk az elemzésbe. Az így összegyűjtött információkat kategorizáltuk a 3. táblázatban jelölt diagnózisok szerint, és ellenőriztük, hogy a EuroHOPE-BRIDGE adatbázisban rögzített diagnózisok láthatók-e a kórlapon is; az eltéréseket rögzítettük.

A EuroHOPE-BRIDGE kutatás 6 fóbb mútéti kategóriát vizsgált, ezekre vonatkozóan néztük az egyezést az Orvosi Eljárások Nemzetközi Osztályozásának (OENO) kódjai alapján (4. táblázat). Egyező eset az, amely az adott rekordra és mütéttípusra vonatkozóan ugyanazt az információt tartalmazza. Eltérést abban az esetben rögzítettünk, ha valamely mútéttípus csak az egyik adatbázisban szerepelt.

\section{Eredmények}

A vizsgált intézményben 2015-ben az ápolást indokló fődiagnózisként csípőtáji törést megnevező osztályos felvételek közül reprezentatív módon kiválasztott minta 341 rekordot tartalmazott, melyek közül a kizárási kritériumok miatt 65-öt elvetettünk (1. ábra). Az összevetéshez további 17 esetet kellett kizárni, amelyek nem szerepeltek a EuroHOPE-BRIDGE állományban külföldi állampolgárság, egy éven belüli korábbi törés miatt, vagy mert más intézményből átvett betegről volt szó. Az elemzésbe így 259, a kórházi adatbázisban szereplő beteg rekordja került be. A kórházi adatbázisban mind a 259 esetben egyezést találtunk a szövegesen leírt diagnózis és a kódolt, ápolást indokló fódiagnózis között.

A szám, dátum és alfanumerikus kód típusú mezők tartalmi egyezőségére vonatkozó eredmények minimális eltérést mutattak a két adatbázis között. A fődiagnózis, a beteg életkora, neme és az osztályról történő távozás dátuma minden esetben azonos volt. A felvételi dátumok között egyetlen esetben tapasztaltunk eltérést. Említésre méltó különbség a beteg további sorsának kódolása esetében tapasztalható: a tíz megfigyelt eltérésből négy esetében a EuroHOPE-BRIDGE adatbázis szerint az otthonába távozott a beteg, a kórlap szerint viszont szociális otthonba. Négy másik esetben „más intézménybe áthelyezve" található a kórházi adatbázisban, míg a EuroHOPE-BRIDGE állományban az előzőhöz hasonlóan szintén „otthonába bocsátva” kódon szerepel a beteg. A kórházi adatbázis elemzésekor észleltük, hogy a szociális otthonba bocsátott betegek esetében rendszertelen volt a távozási hely kódolása, előfordult, hogy csak az epikrízisben jelölték a pontos távozási helyet (szociális

4. táblázat |A mútétek típusának egyezésvizsgálata

\begin{tabular}{|c|c|c|c|c|c|}
\hline \multicolumn{6}{|c|}{ OENO-kódok és elemzett esetszámok } \\
\hline A műtét típusa & $\begin{array}{l}\text { Az OENO-kódok besorolása } \\
\text { a EuroHOPE-BRIDGE } \\
\text { projektben }\end{array}$ & $\begin{array}{l}\text { Esetszám: } \\
\text { EuroHOPE- } \\
\text { BRIDGE }\end{array}$ & $\begin{array}{l}\text { Esetszám: } \\
\text { intézményi } \\
\text { adatbázis }\end{array}$ & $\begin{array}{c}\text { Csak } \\
\text { a EuroHOPE- } \\
\text { BRIDGE adatbá- } \\
\text { zisban szereplő } \\
\text { esetszám }\end{array}$ & $\begin{array}{c}\text { Csak } \\
\text { az intézményi } \\
\text { adatbázisban } \\
\text { szereplő } \\
\text { esetszám }\end{array}$ \\
\hline Hemiartroplasztika* & 58169 & 24 & 22 & 2 & 0 \\
\hline Teljes csípőprotézis* & $58151,5815 \mathrm{E}, 58150$ & 12 & 9 & 4 & 1 \\
\hline Combnyakcsavarozás, csavarozás* * & $57903,57904,5790 \mathrm{~F}, 57924$ & 63 & 61 & 2 & 0 \\
\hline DHS-szintézis & $57908,5792 \mathrm{R}$ & 10 & 10 & 0 & 0 \\
\hline Gamma-szegezés & 83624 & 141 & 141 & 0 & 0 \\
\hline Velőűrszegezés & $83626,8362 \mathrm{C}, 83620,5790 \mathrm{~A}$ & 1 & 0 & 1 & 0 \\
\hline
\end{tabular}

*Az intézményi adatok rögzítésekor a cementes és a nem cementes eljárásokat összevontuk.

**A EuroHOPE-BRIDGE kutatás módszertana miatt összevont mútéti kategóriák.

DHS = dinamikus csípőcsavar; OENO = Orvosi Eljárások Nemzetközi Osztályozása 
Beválogatás:

2015. 01. 01.-2015. 12. 31.

BNO-10: S72.0, S72.1, S72.2 341 eset
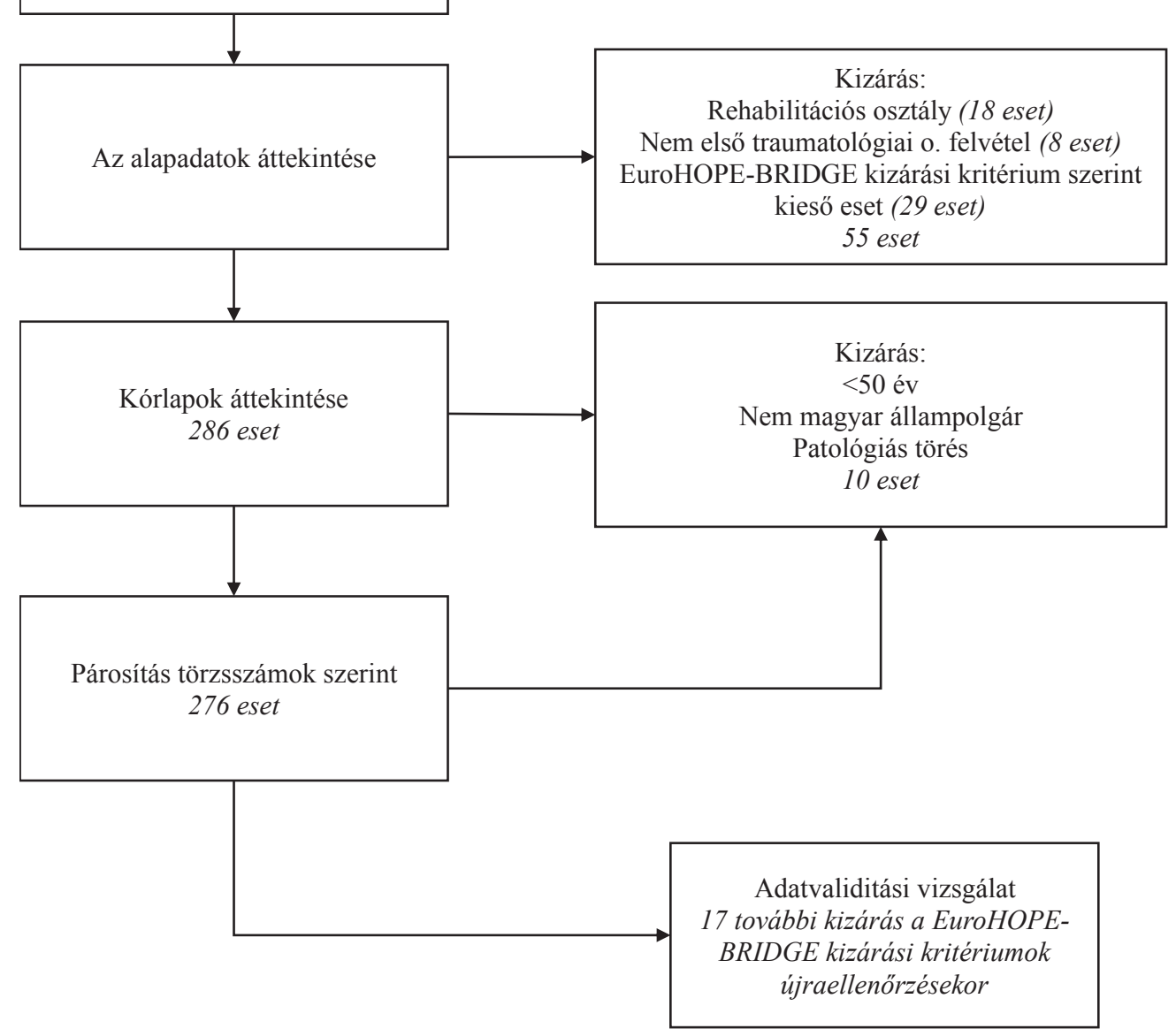

1. ábra

\footnotetext{
Adatleválogatási folyamatábra

$\mathrm{BNO}=$ Betegségek Nemzetközi Osztályozása
}

otthont), a kódolt információ „otthonába bocsátva” volt.

A műtétek dátumai között összesen hat eltérést figyelhettünk meg, ebből kettő volt az, amely meghaladta a \pm 1 napot. Ebben a két esetben részletesen áttekintettük a kórházi adattáblát. Egy esetben az eltérést egy feladott mütéti kísérlet okozta - ennek az elemzésből történő kizárása esetén megszû́nik az eltérés -, a másik esetben a kórházi és a EuroHOPE-BRIDGE adatbázisok között eltérés figyelhető meg. Az egynapos eltéréseket tartalmazó négy esetre vonatkozóan a kórlapelemzés nem ad pontos magyarázatot.

A két adatbázisban feltüntetett mútéttípusok összevetése az OENO-kódok egyeztetésével történt, ennek eredményei a 4. táblázatban láthatók. Nem találtunk eltérést a gamma-szegezés és a DHS-szintézis típusú mûtétek esetén, és csak minimális volt az eltérés a velőűrszegezés és a hemiartroszkópos mütétek esetében (4. táblázat). Combnyak- és egyéb csavarozás esetében összesen két eltérés volt. Mindkét esetben a EuroHOPEBRIDGE adatbázisban két mútétet rögzítettek a beteghez, míg a kórlapban csak a gamma-szegezést jelölték. Ez utóbbi mútéttípusra vonatkozóan mindkét rekord egyezést mutat a két adatbázis között. A velőưrszegezés egyetlen eltérése abból származik, hogy a betegen két mütétet hajtottak végre. A kórlapon fellelhető az első gamma-szegezés és a második velőưrszegezés is, de az egyezésvizsgálathoz csak az első műtétet vettük figyelembe. A EuroHOPE-BRIDGE adatbázis mindkét mútétet tartalmazza, így a második esetében értelemszerú az eltérés.

A társbetegségekre és a szövődményekre vonatkozó adategyezési vizsgálat változó eredményeket hozott. Igen magas arányú eltérések tapasztalhatók a magas vérnyomás, a diabetes és a szív-ér rendszeri betegségek jelölésében. Az egyéb társbetegségek esetén alacsonyabb, ám a nem szabad szöveges típusú adatokhoz képest lényegesen magasabb arányú eltérések láthatók (5. táblá- 
5. táblázat |A társbetegségekre vonatkozó egyezésvizsgálat $(\mathrm{n}=259)$

\begin{tabular}{|c|c|c|c|c|c|c|}
\hline \multirow[b]{2}{*}{$\begin{array}{l}\text { A vizsgált társbetegségek } \\
\text { megnevezése }\end{array}$} & \multicolumn{6}{|c|}{ A vizsgált társbetegségek előfordulása (esetszám) } \\
\hline & $\begin{array}{c}\text { A kórházi } \\
\text { adatbázisban (1) }\end{array}$ & $\begin{array}{c}\text { Csak a kórházi } \\
\text { adatbázisban (2) }\end{array}$ & $\begin{array}{l}\text { A EuroHOPE- } \\
\text { BRIDGE } \\
\text { adatbázisban (3) }\end{array}$ & $\begin{array}{l}\text { Csak a EuroHOPE- } \\
\text { BRIDGE } \\
\text { adatbázisban (4) }\end{array}$ & $\begin{array}{l}\text { A két állomány } \\
\text { közötti eltérések } \\
\text { száma } \\
(5)=(2)+(4)\end{array}$ & $\begin{array}{l}\text { Mindkét } \\
\text { állományban } \\
\text { (egyezés) }\end{array}$ \\
\hline Magas vérnyomás & 147 & 103 & 59 & 15 & 118 & 44 \\
\hline Coronariabetegség & 53 & 39 & 29 & 15 & 54 & 14 \\
\hline Pitvarfibrilláció & 14 & 6 & 17 & 9 & 15 & 8 \\
\hline Szívelégtelenség & 13 & 8 & 21 & 16 & 24 & 5 \\
\hline Diabetes & 48 & 31 & 21 & 4 & 35 & 17 \\
\hline Atherosclerosis & 18 & 16 & 29 & 27 & 43 & 2 \\
\hline Daganatos megbetegedés & 26 & 23 & 6 & 3 & 26 & 3 \\
\hline COPD és asztma & 11 & 8 & 9 & 6 & 14 & 3 \\
\hline Dementia & 34 & 22 & 23 & 11 & 33 & 12 \\
\hline Depresszió & 7 & 7 & 5 & 5 & 12 & 0 \\
\hline Parkinson-kór & 3 & 3 & 0 & 0 & 3 & 0 \\
\hline Mentális rendellenességek & 18 & 18 & 4 & 4 & 22 & 0 \\
\hline Veseelégtelenség & 9 & 6 & 9 & 6 & 12 & 3 \\
\hline Alkoholbetegség & 2 & 0 & 6 & 4 & 4 & 2 \\
\hline Stroke & 19 & 16 & 14 & 11 & 27 & 3 \\
\hline
\end{tabular}

COPD = krónikus obstruktív tüdőbetegség

6. táblázat |A szövődményekre vonatkozó egyezésvizsgálat ( $\quad$ = 259)

\begin{tabular}{|c|c|c|c|c|c|c|}
\hline Szövődmények & $\begin{array}{l}\text { A kórházi } \\
\text { adatbázisban } \\
\text { rögzített } \\
\text { diagnózis (1) }\end{array}$ & $\begin{array}{l}\text { Csak a kórházi } \\
\text { adatbázisban } \\
\text { szereplő } \\
\text { diagnózis (2) }\end{array}$ & $\begin{array}{l}\text { A EuroHOPE- } \\
\text { BRIDGE } \\
\text { adatbázisban } \\
\text { rögzített } \\
\text { diagnózis (3) }\end{array}$ & $\begin{array}{c}\text { Csak a } \\
\text { EuroHOPE- } \\
\text { BRIDGE } \\
\text { adatbázisban } \\
\text { szereplő esetek } \\
\text { száma (4) }\end{array}$ & $\begin{array}{l}\text { A EuroHOPE- } \\
\text { BRIDGE és a } \\
\text { kórházi adatbázis } \\
\text { közötti eltérések } \\
\text { száma } \\
(5)=(2)+(4)\end{array}$ & $\begin{array}{c}\text { Mindkét } \\
\text { állományban } \\
\text { szereplő } \\
\text { diagnózis } \\
\text { (egyezés) }\end{array}$ \\
\hline Tüdőembólia & 1 & 0 & 1 & 0 & 0 & 1 \\
\hline Akut myocardialis infarctus & 3 & 1 & 4 & 2 & 3 & 2 \\
\hline Phlebitis és thrombophlebitis & 1 & 0 & 1 & 0 & 0 & 1 \\
\hline Pneumonia & 5 & 4 & 2 & 1 & 5 & 1 \\
\hline $\begin{array}{l}\text { Ortopédiai protézisekhez, } \\
\text { implantátumokhoz kötődő fertőzés }\end{array}$ & 0 & 0 & 0 & 0 & 0 & 0 \\
\hline Húgyúti fertőzés & 14 & 12 & 2 & 0 & 12 & 2 \\
\hline Együtt & 24 & 17 & 10 & 3 & 20 & 7 \\
\hline
\end{tabular}

zat). A szövődményekre vonatkozó elemzést a 6. táblázat ismerteti, hasonlóan nagy arányú eltérések figyelhetők meg.

\section{Megbeszélés}

A EuroHOPE-BRIDGE kutatáshoz kapcsolódó tanulmányok [1, 14] mellett Magyarországon több olyan publikáció is napvilágot látott már, amely a hazai finanszírozási célú adatbázisra támaszkodva végez epidemiológiai elemzést [15-17]. Ezek a vizsgálatok gyakorta kerülnek a szakmai viták kereszttüzébe, mivel kérdéses, hogy az adatgyưjtés célja hogyan és mennyire befolyásolja az adatminőséget [18-20]. A viták ellenére kevés hazai kutatás vizsgálja az adatok validitásának kérdését $[7,20$, 21], és diagnózistól vagy vizsgálattípustól függően ezek a kutatások is eltérő következtetésekre juthatnak.

Fontosnak tartjuk ezért, hogy részben a EuroHOPEBRIDGE kutatás eredményeit alátámasztandó, részben további elemzéseket megalapozandó, megvizsgáljuk a csípőtáji törések esetében a finanszírozási célú adatok megbízhatóságát. Ezen kutatási célon túlmutatóan pe- 
dig fontos, hogy ismerjük ennek a nemzetközi szinten is kiemelkedően részletes és régóta gyưjtött adatbázisnak (az OEP - NEAK betegforgalmi adatbázisa) az erósségeit, korlátait, és ezek fényében végezhessünk el rá támaszkodó további elemzéseket. A vizsgálat eredményei alapján az adatvaliditásra vonatkozóan adattípustól függően tudunk következtetéseket levonni. Mivel a kórlapelemzést egyetlen intézményben hajtottuk végre, a megállapítások országos szintű általánosítása akkor fogadható el, ha feltételezzük, hogy a kódolási gyakorlat hasonló az ország többi, csípőtáji törést szenvedő betegek ellátását végző intézményében $[18,21]$.

Vizsgálatunk egyik fó kérdése az ápolást indokló födiagnózisok helyességének vizsgálata volt, erre vonatkozóan a kórlapok és az OEP felé jelentett, illetve onnan leválogatott adatok között lényegi eltérést nem találtunk. A szám, dátum és alfanumerikus kód típusú mezők vizsgálata során megállapítottuk, hogy az eltérések mértéke elhanyagolható. Ezen megállapítások alapján, és feltételezve az országosan megközelítőleg egységes kódolási, adatjelentési szokásokat $[7,18]$, kijelenthető, hogy a csípőtáji törésekre vonatkozó EuroHOPE-BRIDGE adatállomány alkalmas lehet a strukturált, kódolt adatelemekre támaszkodó mélyebb elemzésekre. Vizsgálhatók tehát a nemzetközi szakirodalom szerint a túlélés szempontjából fontos tényezők közül a dátumokra épülő indikátorok (például a felvétel és a mútét között eltelt idő), de érdemes figyelembe venni, hogy néhány esetben a dekurzus szövege és a kódolt dátummező között egynapos eltérést találtunk. Ennek oka az intézményi kódolásiadatrögzítési gyakorlatban keresendő. A medikai szoftver nem engedélyezi a visszamenóleges dátummegadást, így ha egy mütétet az elvégzés utáni napon rögzítenek az informatikai rendszerben, kialakul a megfigyelt eltérés.

A mútéttípusok vizsgálata során nagyobb eltérést csak a teljes csípőprotézis-mútétek esetében tapasztaltunk; a többi mútéttípusra vonatkozóan elenyésző mértékű az eltérések száma, amelyeket három esetben (combnyakés egyéb csavarozás, illetve velőürszegezés) a betegen elvégzett több mütét magyaráz. Ezen eredmények alapján a mütétek típusára vonatkozó adatok felhasználhatók további elemzésekre.

Jelentős eltérés tapasztalható a társbetegségek esetében. Az eltérések száma minden diagnózis esetén meghaladja az egyező, azaz mindkét adatbázisban rögzített esetek számát. Az alkoholbetegséget kivéve minden társbetegség esetén megfigyelhető, hogy a kórlapon említett betegségeknek több mint a fele nem jelenik meg a EuroHOPE-BRIDGE adatbázisban. Ezen irányú eltérés az atherosclerosis és a daganatos megbetegedések esetén a legnagyobb. Hasonlóan rossz eredményeket tapasztalhatunk, ha a EuroHOPE-BRIDGE adatbázisban rögzített adatok kórlapon való szereplését nézzük: a magas vérnyomás és a diabetes kivételével minden betegség esetén legalább 40\%-os eltérést találtunk. Az eltéréseknek részben magyarázata a EuroHOPE-BRIDGE és az intézményi kutatás közötti eltérő adatgyứjtési módszer- tan. Míg a kórlapon a beteg által említett vagy a kórházban diagnosztizált betegségek megjelenhettek, addig a EuroHOPE-BRIDGE kizárólag a csípőtáji töréssel történt kórházi felvételt megelőző 365 napon, kórházi események során kódolt fơ- vagy egyéb diagnózisokat és a beteg által kiváltott specifikus gyógyszereket vette figyelembe. Ezt a különbséget tekintve is kijelenthető, hogy a EuroHOPE-BRIDGE adatbázis nem alkalmas a társbetegségek vizsgálatára, kockázatkiegyenlítésben történő használatra.

A rögzített szövődmények előfordulása mindkét adatbázisban alacsony. Lényegi eltérés a húgyúti fertőzések esetében látható: míg a kórházi állományban 14 esetben jelenik meg, közülük csupán két betegnél jelentették ezt a finanszírozási adatbázisba, azaz ez a szövődmény jelentősen 'aluljelentett'. Mindezeket egybevetve megállapítható, hogy a kórházi adatok között talált, összesen 24 szövődmény közül csak 7 jelent meg a EuroHOPEBRIDGE állományban, így összességében a szövődmények információtartalma a finanszírozási adatbázisban erősen megkérdőjelezhető, kutatási célra nem alkalmas.

\section{Következtetés}

Elemzésünk alapján megállapítható, hogy a EuroHOPEBRIDGE adatbázis alkalmas lehet a strukturált adatelemekre, azaz a dátum, szám, alfanumerikus kód típusú mezőkre támaszkodó további elemzésekre. Az adatminőség alapján a EuroHOPE-BRIDGE adatbázis alkalmas életkori csoportok és nemek szerinti elemzésekre. A további sorsban tapasztalt eltéréseket a kórházi adatok és a vizsgálat alapjául szolgáló adatbázis között a továbbiakban torzító tényezőként figyelembe kell venni, ha elemzési kérdésként a szociális otthoni vagy a saját otthoni környezet szerepe merül fel.

Az eredmények alapján nem igazolható, hogy a EuroHOPE-BRIDGE kutatásban kockázatkiegyenlítéshez alkalmazott társbetegségek és szövődmények azonosításához használt adatok kellően pontosak lennének.

Jelen vizsgálatunk erôssége az esetszintü, szöveges adatokra támaszkodó adatelemzés, gyengeségei között viszont meg kell említeni, hogy egy országos adatbázis adatvaliditását egy intézmény adatain keresztül vizsgáltuk. Így nem bizonyos, hogy pontos képet kapunk az adatok helyességéről, az eltérések azonban a strukturált (szám, dátum, alfanumerikus kód) mezők esetében olyan kicsik, hogy még a kódolási szokások bizonyos mértékű eltérése esetén is feltételezhető, hogy az adatok a fent említett kitételekkel alkalmasak a mélyebb elemzésekre.

Anyagi támogatás: A szerzők a közlemény megírásáért és a közölt kutatásért anyagi támogatásban nem részesültek.

Szerzôi munkamegosztás: S. C.: Intézményi adatgyűjtés, intézményi elemzések és az összevető vizsgálat elvég- 
zése, szövegezés. B. É.: A EuroHOPE és BRIDGE kutatásokhoz kapcsolódó elemzések és adatok rendelkezésre bocsátása, véleményezés, tartalmi ellenőrzés, szövegezés. A cikk végleges változatát mindkét szerző elolvasta és jóváhagyta.

\section{Érdekeltségek: A szerző́knek nincsenek érdekeltségeik.}

\section{Köszönetnyilvánítás}

A cikk megszületéséért a szerzők köszönetet mondanak a EuroHOPEBRIDGE kutatás vezetốinek és a vizsgálatban közremúködő kórház orvosigazgatójának és rendszergazdájának az adatok rendelkezésre bocsátásáért és a szakmai támogatásért.

\section{Irodalom}

[1] Flóris I, Belicza É. Analysis of hip fracture care in Hungary be tween 2004-2009. [A csípótáji törések hazai ellátásának elemzése a 2004-2009 közötti időszakban.] Orv Hetil. 2016; 157: 16421648. [Hungarian]

[2] Belicza É, Kullmann L, Boján F. The effect of performanceoriented financing on the quality of hospital discharge data. [A teljesítményelvú finanszírozás hatása a kórházi adatszolgáltatás minőségére.] Lege Artis Med. 1996; 6: 252-260. [Hungarian]

[3] Khan A, Ramsey K, Ballard C, et al. Limited accuracy of administrative data for the identification and classification of adult congenital heart disease. J Am Heart Assoc. 2018; 7: e007378.

[4] Tan AC, Armstrong E, Close J, et al. Data quality audit of a clinical quality registry: a generic framework and case study of the Australian and New Zealand Hip Fracture Registry. BM] Open Qual. 2019; 8: e000490.

[5] van Walraven C, Austin P. Administrative database research has unique characteristics that can risk biased results. J Clin Epidemiol. 2012; 65: 126-131.

[6] Yamana H, Moriwaki M, Horiguchi H, et al. Validity of diagnoses, procedures, and laboratory data in Japanese administrative data. J Epidemiol. 2017; 27: 476-482.

[7] Ajtay A, Oberfrank F, Bereczki D. Applicability of hospital reports submitted for reimbursement purposes for epidemiological studies based on the example of ischemic cerebrovascular diseases. [A kórházi adatlapok jelentéseinek alkalmazhatósága epidemiológiai elemzésekre az ischaemiás cerebrovascularis betegségek példája alapján.] Orv Hetil. 2015; 156: 1540-1546. [Hungarian]

[8] Gregson CL, Carson C, Amuzu A, et al. The association between graded physical activity in postmenopausal British women, and the prevalence and incidence of hip and wrist fractures. Age Ageing 2010; 39: 565-574.

[9] Griffiths F, Mason V, Boardman F, et al. Evaluating recovery following hip fracture: a qualitative interview study of what is important to patients. BMJ Open 2015; 5: e005406.

[10] Löfgren S, Hedström M, Ekström W, et al. Power to the patient: care tracks and empowerment a recipe for improving rehabilita- tion for hip fracture patients. Scand J Caring Sci. 2015; 29: 462469.

[11] Colais P, Pinnarelli L, Fusco D, et al. The impact of a pay-forperformance system on timing to hip fracture surgery: experience from the Lazio Region (Italy). BMC Health Serv Res. 2013; 13: 393.

[12] Nielsen KA, Jensen NC, Jensen CM, et al. Quality of care and 30 day mortality among patients with hip fractures: a nationwide cohort study. BMC Health Serv Res. 2009; 9: 186.

[13] Pinnarelli L, Nuti S, Sorge C, et al. What drives hospital performance? The impact of comparative outcome evaluation of patients admitted for hip fracture in two Italian regions. BMJ Qual Saf. 2012; 21: 127-134.

[14] Belicza É, Mihalicza P, Lám J, et al. Methods of the EuroHOPE research program. [A EuroHOPE kutatási program módszertana.] Orv Hetil. 2016; 157: 1619-1625. [Hungarian]

[15] Juhász K, Boncz I, Kanizsai P, et al. Analysis of the prognostic factors influencing the time elapsing until the contralateral hip fracture. [Az ellenoldali csípőtáji törésig eltelt időt befolyásoló prognosztikai tényezők vizsgálata.] Orv Hetil. 2018; 159: 15431547. [Hungarian]

[16] Folyovich A. Acute ischaemic stroke and its complications. Iimmunological and epidemiological research. Doctoral dissertation. [Akut ischaemiás stroke és szövődményei - immunológiai vizsgálatok és epidemiológiai felmérés. Doktori értekezés.] Semmelweis Egyetem, Klinikai Orvostudományok Doktori Iskola, Budapest, 2015. Doi: 10.14753/SE.2016.1897. [Hungarian]

[17] Juhász K, Boncz I, Kanizsai P, et al. Analysis of mortality and its predictors in patients with contralateral hip fracture after femoral neck fracture. [Ellenoldali csípőtáji törésekkel összefüggő halálozás és kockázati tényezőinek vizsgálata.] Orv Hetil. 2017; 158: 783-790. [Hungarian]

[18] Imre L, Szabó T, Szummer Cs. The DRG technique and the coding practice of Hungarian hospitals based on the survey of the Association of Health Financing Advisors. [A HBCs finanszírozási technika, valamint a magyar kórházak kódolási gyakorlata az Egészségügyi Finanszírozási Tanácsadók Egyesülete (EFTE) kérdőíves felmérése alapján.] IME 2005; 4(9): 18-22. [Hungarian]

[19] Benedek, Zs. Analysis of patients with colorectal cancer treated with surgery in 2015 and 2016, using a statistical model. [A 2015-ben és 2016-ban vastag- és végbélmütéten átesett daganatos betegek adatainak vizsgálata matematikai-statisztikai modellel.] Orv Hetil. 2019; 160: 426-434. [Hungarian]

[20] Jánosi A, Póth A, Zorándi Á, et al. Treatment of patients with myocardial infarction in Hungary on the basis of available health data. [Szívinfarktus miatt kezelt betegek ellátásának vizsgálata Magyarországon a rendelkezésre álló egészségügyi adatok alapján.] Orv Hetil. 2016; 157: 89-93. [Hungarian]

[21] Surján G. Questions on validity of International Classification of Diseases-coded diagnoses. Int J Med Inform. 1999; 54: 77-95.

(Surján Cecília, Budapest, Kútvölgyi út 2., 1125 e-mail: surjan@emk.semmelweis.hu)

A cikk a Creative Commons Attribution 4.0 International License (https://creativecommons.org/licenses/by/4.0/) feltételei szerint publikált Open Access közlemény, melynek szellemében a cikk bármilyen médiumban szabadon felhasználható, megosztható és újraközölhetö, feltéve, hogy az eredeti szerző és a közlés helye, illetve a CC License linkje és az esetlegesen végrehajtott módosítások feltüntetésre kerülnek. (SID_1) 